\title{
Brief Analysis on Problems Existing in College Administrative Management and Reform Measures
}

\author{
Yinglan Yu \\ Yanbian University, Yanji Jilin, 133002, China
}

Keywords: College and universities, Administrative management, Problems, Reform measures.

\begin{abstract}
College administrative management level is one of important standards to judge the overall level of universities and colleges. Under the new circumstance of higher educational reform in China, college administrative management plays a very important role in higher educational reform. Therefore, improving the administrative management capability and work efficiency in Chinese universities and colleges will play significant function in promoting university reform in china. This article discusses the important value of college administrative management, analyzed existing problems, and elaborated some specific reform measures to solve these problems.
\end{abstract}

\section{Introduction}

College administrative management mainly refers to various management activities conducted by party and government departments in college and universities. That is to say, colleges focus on relevant administrative measures and methods to lead and guide all staff and students after they have set its own work objective. In this way, key work can be completed in the school. For college administrative work, the most important is to properly deal with relationship between different internal departments, and between teachers and students. College administrative management owns significant particularity in management domain. Thus, college administrative management is of great value to strengthen education teaching management and guarantee the quality of running a school. Only through intensifying college administrative management can achieve the harmony among relevant departments and school's rapid and smooth running.

\section{Important value of China's college administrative management}

College administrative management is a basic condition to carry out teaching and scientific research work. College administrative management has owned obvious instructive, restraint and adjusting function in university management system. It has important values as below: firstly, it can guarantee the reform and development of college administrative management. The supportability of college administrative management is presented through its own service function. China's college administrative management would usually involve many aspects. The administrative management in each college is unimportant issue but will causes huge obstacles for the overall situation of college development if handled improperly. Therefore, college administrative should develop its service function to appropriately deal with different relations in administrative management. Secondly, promote the reform and development of college administration. Colleges mainly focus on the management and service of higher education talents for talent cultivation. In this way, it will involve many administrative department of the school. Due to huge differences between different departments, conditions which cannot be coordinated will happen in practical work. In this case, spare every effort to develop the coordinating role of each internal department to promote the solidarity cooperation between each other and sustainable development of colleges. Thirdly, promote 
better development of college administrative management. The main function of China's college administrative management is to supervise the work condition of departments and faculties and staffs in colleges and universities to promote them to complete various work and promote the development college administrative career. Thus, the implementation of incentive and performance appraisal measures can establish methods to match with college administrative management to lay solid foundation for normal operation of college administrative management.

\section{Analysis on problems existing in China's college administrative management}

First is the problem of laying more emphasis on teaching than administrative management. College administrative management is organized and planned activities implemented by colleges and universities through specific institutions and system so as to truly help colleges' manpower, funds and material to exert more important function and to effectively implement each work task with high quality for teaching objective fulfillment. However, nowadays, some managers in colleges and universities do not have deep understanding on administrative management so as to cause huge mistakes. They think administrative management is to simple transcription and inflexible information. Although administrative management is simple and even some colleges regard it as accessories so that leadership of colleges and relevant departments overemphasize teaching and pay little attention to administrative managers. This will impact the initiative of administrative managers. Based on this, in college administrative work, college leadership and relevant functional departments focus on studies on teaching and scientific research achievements but neglect the fact that the foundation should be administrative management.

Second is that administrative management mechanism is not sound. Compared with other types of units, college administrative management mechanism is single and the restraint method for manager is work post responsibility and various rules and regulations. In this way, although it can guarantee all kinds of administrative orders unimpeded, it will greatly limit the subjective initiative of administrative mangers. It would easily lead to the administrative management personnel's mentality of never making mistakes or working carelessly with sluggishness if they work under this kind of management system. In addition, work in college administrative management department is very complicated, some personnel are lack of professional knowledge. When dealing with specific work, they are short of flexibility. As problems of unsound system and lagging working method in college administrative department appeared in recent years, it is especially common that they have bad attitude toward teachers and students even with abusive expressions. This has greatly hindered the improvement of college administrative management efficiency.

Thirdly, there is few cooperation between departments in colleges. The definition of college administrative management work is to use management to strengthen the connection among different departments in colleges so as to get the cooperation between each department closer and realize unified, harmonious and sustainable development. But under current college administrative management mechanism, college administrative management departments use strict grade division and different departments are divided between each management layer to manage specific affairs. This kind of management methods may help the work responsibility division more refined and help mangers to clarify their own duties, it will also reduce the communication and exchange between each department so that each department knows little about the other departments' work and it will be hard to realize tacit cooperation. Once problems happen, each department would care about its own interest instead of undertaking any responsibilities so that their work cannot be closely coordinated and it causes huge obstacles for college to carry out administrative management activities.

Fourthly, professional ethics education is insufficient. Although education legislation in China has made great progress in recent years, problems of non-compliance to laws and lax enforcement of laws are still existing so that educational laws and regulations cannot be implemented well. Some college administrative management personnel lack rudimentary professional ethics so that it is impossible to realize justice and fairness but likely to produce corruption problems such as bribery and black box 
operation. Thus, college management leadership must pay high attention to problems and solve problems through intensifying professional ethics education.

\section{Specific reform measures on problems existing in China's college administrative management}

\section{Transfer ideology practically and strengthen administration work}

To achieve managing the school by law, colleges must practically transfer ideology and establish the new ideology of improving administrative management effect. Considering continuous development of social economy, competition between colleges is becoming more intense. How to stand out in increasingly fierce market competition, colleges must carefully implement "Higher Education Law" and "Teacher's Law", and also should try best to learn from brother schools' advanced experience in running school and make yearly studies on the development direction to fully transfer education ideology and profoundly study the meaning of administrative management efficiency. Firstly, strengthen college administrative management and carry out discussion and cultivation of administrative management personnel participating in management for ideological education; secondly, use democratic, scientific and standard administrative ideology to replace traditional concept and help each administrative management worker to develop efficiency-oriented and strenuous qualities. Thirdly use internal administrative management mechanism reform to strengthen administrative management work and correct wrong concepts in practical administrative management work. Actively advocate the principle of administrative management serving for education teaching, teachers and students, and create an environment focusing more on efficiency and pragmatic work. Only in this way can colleges and universities improve educational and teaching quality and promote the rapid development.

\section{Establish sound college administrative management mechanism}

Based on original administrative management system, update and perfect to truly transfer traditional management methods. Abolish some unsuitable old system, and keep good parts and pay special attention to reasonably conduct the right hand-over to strengthen the development of basic administrative organizations so as to promote the communication and connection between different departments. Try as far as possible to reduce the divergence and conflicts caused by unclear responsibilities to improve the preciseness and standardization of decision-making. Reasonably improve the efficiency of administrative management from institutional aspect. Meanwhile, clarify each position responsibility and analyze main features of each administrative management position accurately to know major duties and limitations of each position. Conduct talent selection and appointment based on position features. Pay more attention to the administrative management staff selection to make sure talent teams in middle and higher management layer are stable so as to improve administrative management personnel's information skills and to transfer the information trend in college administrative management work. Meanwhile, formulate relevant specific performance assessment indicators to improve the strength of college administrative management so that administrative management personnel's initiative can be fully developed to effectively improve the quality of college administrative monument work.

\section{Promote the communication and strengthen cooperation between internal departments in colleges and universities}

One of important missions of college administrative management is to coordinate the work between different department so as to promote the development of higher education and scientific research. Therefore, college and university administrative management cannot work without the communication between each functional departments. Each departments in colleges should rapidly feedback work related contents to cooperative departments so as to promote communication. In this way, information transmission will be more direct to guarantee the information accuracy and 
effectiveness. Through close cooperation between different departments, problems and disadvantages of administrative management can be found to investigate the responsibilities of departments or individuals. It can help related working staffs to undertake self-responsibility to contribute ideas and exert efforts for college development.

\section{Pay attention the professional ethnics education of college administrative management staff}

Firstly, intensify individual professional ethnic knowledge learning. Devote to improving college administrative management personnel's learning initiative, actively learn national education policies, improve Marxism-Leninism theoretical qualities, study administrative management professional literature and improve individual management level and professional ethnic accomplishment. Perfect rules and regulations on college management and standardize college students and teachers' ethnic behaviors with regulations and rules. College administrative managers must exert management right but also should restrain their own behaviors to form steadfast, hardworking and pragmatic working style. Establish more reasonable and sound examination and evaluation system to evaluate administrative managers' professional ethnic condition and make rewards and punishments to promote administrative managers' good professional ethnic manners. Secondly, improve college administrative managers' ideological and political quality and moral qualities. College administrative managers should adhere to regarding the fundamental interest of the school and teachers and students as the basis, persist in seeking truth from facts and have good moral qualities with responsible working attitude and behave in good manner of dealing with people, and keep improving thinking awareness and theoretical level. In this way, individual working level can be improved constantly in practical work. Thirdly, improve psychological quality of college administrative management staff. College administrative work is detailed and complicated including independent work and interrelated work. For example, college administrative mangers must deal with complicated objects including local governmental officials, peers in brother schools, and leaders, collogues and students in the school. To properly complete various working tasks, multiple related factors must be taken into consideration comprehensively to guarantee strong psychological quality and anti-pressure ability. Therefore, colleges and universities administrative mangers must have positive and open-minded personalities to solve various problems in full sail, but also should truly love college administrative management work. Because only true love can help them get into work passionately and strive to get best performance.

\section{Conclusion}

To sum up, seeing from the practical condition in China, China's colleges and universities rank far behind western countries. Large amount of excellent talents are studying abroad and many families immigrate so as to get their children to receive better education. This has made excellent overseas students choose to work abroad. Only very few students choose to get back to China. The situation is bad for improving China's comprehensive competitive strength. Analysis on many problems existing in China's college administrative management proves that higher education in China is faced up with great challenges. Therefore, it requires to take targeted reform measures to solve problems. The author firmly believes that as long as persist in implementing various reform measures, it is certain that practical problems in current college administrative management will be solved to promote new development in China’s higher education enterprise.

\section{References}

[1] Liu Qian. Study on problems existing in China's college administrative management and countermeasures . Manager' Journal, 2013 (2).

[2] Chen Minhong. Brief discussion on problems existing in China's college administrative management, reasons and countermeasures . Nan Fang Lun Kan, 2013 (6). 
[3] Wu Ruikun, Zhang Ganggang. Problems existing in college administrative management and countermeasures. Journal of South China University of Technology (Social Science Edition), 2013 (6).

[4] Li Xue. Problems in college administrative management and coping strategies . Education forum, $2013(32)$

[5] Kan Geng. Discussion on how to effectively improve working efficiency of college administrative management . Journal of Jiamusi Vocational College, 2014 (8)

[6] Zhang Liang. Brief discussion on problems in college administrative management and countermeasures . Contemporary Education Research and Teaching Practice, 2014 (12) 